\title{
SISTEM TEMU KEMBALI CITRA UNTUK $E$ - COMMERCE MENGGUNAKAN PROSEDUR PENCARIAN DUA FASE DENGAN FITUR HISTOGRAM MULTI TEKSTON
}

\author{
Nurissaidah Ulinnuha ${ }^{1)}$, Halimatus Sa'dyah ${ }^{2)}$ \\ Fakultas Sains dan Teknologi, Universitas Islam Negeri Sunan Ampel Surabaya ${ }^{1)}$ \\ Departemen Teknik Multimedia Kreatif, Politeknik Elektronika Negeri Surabaya ${ }^{2)}$ \\ Email : nuris.ulinnuha@uinsby.ac.id ${ }^{1)}$, halimatus@pens.ac.id ${ }^{2}$
}

\begin{abstract}
Abstrak
Bertumbuhnya bisnis e-commerce di internet membuka ranah penelitian baru di bidang sistem temu kembali citra khusus untuk produk-produk yang sedang diperjual belikan secata online. Pada makalah ini, diusulkan sistem temu kembali citra untuk e-commerce dengan prosedur pencarian dua fase menggunakan fitur histogram multi tekston (MTH-2). Pada proses uji coba, sistem ini dibandingkan dengan sistem pencarian satu fase dengan fitur yang sama (MTH-1) dan sistem temu kembali citra yang menggunakan algoritma SIFT. Hasil uji coba menunjukkan bahwa algoritma SIFT menghasilkan presisi rata-rata dan recall rata-rata sebesar 100\% dan 42\%, MTH-1 menghasilkan presisi rata-rata sebesar 32\% dan 63\%. Sedangkan sistem MTH-2 menghasilkan nilai presisi dan recall rata-rata $60 \%$ dan 63\%. Berdasarkan hasil uji coba ini dapat disimpulkan bahwa sistem MTH2 cocok digunakan untuk dataset produk-produk yang dijual secara online.
\end{abstract}

Kata Kunci: Citra, e-Commerce, Sistem Temu Kembali

\begin{abstract}
The growth of e-commerce business on the internet open a new domain of research in the field of image retrieval system specifically for products that are being traded online. In this paper, the proposed image retrieval system for e-commerce with two-phase search system using multitexton histogram features (MTH-2). In the process of testing, this system compared to a single-phase search system with the same features (MTH-1) and the image retrieval system using SIFT algorithm. Experimental results show that the algorithm SIFT produce average precision and recall values of $100 \%$ and $42 \%$, MTH-1 produces average precision and recall values of $32 \%$ and $63 \%$, while MTH-2 system produces average precision and recall values of $60 \%$ and $63 \%$. Based on the results of this trial can be concluded that the system MTH-2 is suitable for datasets products that are being traded online.
\end{abstract}

Keywords : Image, e-Commerce, Information Retrieval

\section{PENDAHULUAN}

Pada era teknologi informasi seperti sekarang ini, Image Retrieval atau sistem temu kembali citra menjadi teknologi yang potensial untuk digabungkan dengan sistem jual beli online demi menaikkan nilai jual sistem jual beli online tersebut. Adanya fungsi sistem temu kembali citra pada sebuah sistem jual beli online dapat mempermudah pembeli untuk mencari informasi lengkap tentang suatu produk dengan menggunakan data citra sebagai masukan.

Data citra dari produk pada sistem jual beli online memiliki karakteristik yang berbeda dengan citra panorama lainnya. Perbedaan antar citra panorama dapat diwakili oleh fitur tekstur dan warna sedangkan perbedaan antar citra produk tidak cukup diwakili dengan fitur tekstur dan warna saja. Untuk mengenali perbedaan antar citra produk, dibutuhkan fitur lain yaitu fitur bentuk atau tepi citra.

Fitur warna dari citra produk kurang relevan jika dijadikan fitur tunggal pada sistem temu kembali citra. Hal ini disebabkan banyaknya variasi warna pada produk sejenis serta adanya kesamaan warna pada produk yang tidak sejenis. Hasil uji korelasi antara histogram warna dan jenis produk menghasilkan nilai koefisien $r$ yang berkisar antara 0.12 sampai 0.28 . Uji ini membuktikan bahwa secara statistik, histogram warna tidak dapat dijadikan fitur tunggal pada sistem temu kembali citra untuk kasus citra produk. 
Ada beberapa metode yang diusulkan berkaitan dengan sistem temu kembali citra yang menitik beratkan fitur bentuk dan tekstur. Jain beserta timnya memperkenalkan Edge Direction Histogram (EDH) [1][2]. Metode ini dapat mengatasi permasalahan temu kembali citra pada data yang sudah mengalami proses translasi, rotasi, dan perubahan ukuran. Namun, EDH hanya cocok digunakan untuk data citra yang tergambar pada bidang datar.

Selanjutnya, Lowe memperkenalkan metode Scale Invariant Feature Transform (SIFT) untuk mengenali fitur lokal pada citra. Metode SIFT mengenali bentuk citra melalui titik-tiik yang membentuk tepian citra, oleh karenanya kemampuan metode SIFT dalam mengenali bentuk citra di atas rata-rata, melebihi metode lain pada kelasnya. Namun, metode ini memiliki kekurangan pada kompleksitasnya yang tinggi dan berujung pada mahalnya biaya komputasi [3].

Benarjee beserta tim memperkenalkan metode pengenalan bentuk citra dengan pendekatan tekstur dan warna yang direpresentasikan dengan fitur Texton Co-occurrence Matrix (TCM). TCM memberikan informasi tentang korelasi antar tekston pada citra. TCM sesuai untuk permasalahan temu kembali citra yang menitikberatkan pada fitur bentuk, warna, dan tekstur dengan kompleksitas perhitungan yang rendah dan biaya komputasi yang murah [4]. Hai-Liu beserta timnya kemudian mengadopsi metode TCM untuk mengembangkan fitur yang bernama Multi Texton Histogram (MTH). MTH menggabungkan manfaat dari TCM dan histogram untuk mempermudah analisa tekstur dan bentuk [5].

Sistem temu kembali citra yang diusulkan dalam makalah ini mengadopsi fitur MTH atau histogram multi tekston untuk menganalisa bentuk dan tekstur dari sebuah citra yang digabungkan dengan prosedur pencarian dua fase. Fase pertama ditujukan untuk mencari kategori citra sedangkan fase kedua ditujukan untuk mencari citra di dalam kategorinya. Adanya penggabungan antara histogram multi tekston dan prosedur pencarian dua fase ini diharapkan dapat menghasilkan sistem temu kembali citra dengan nilai presisi dan recall yang tinggi namun biaya komputasinya rendah.

\section{HISTOGRAM MULTI TEKSTON}

Histogram multi tekston merupakan fitur turunan dari tekston [1]. Histogram multi texton sebenarnya lebih cocok untuk citra pemandangan yang memiliki fitur dominan warna dan tekstur. Namun pada makalah ini, histogram multi tekston digunakan untuk produk dengan batasan sistem pencarian dibuat dua fase dengan kamus citra yang terklasifikasi. Untuk mendapatkan nilai dari histogram multi tekston, langkah-langkah yang harus dilakukan adalah menghitung nilai orientasi tekstur, melakukan kuantisasi pada warna citra serta mendeteksi jenis-jenis elemen tekston. Penjelasan tentang prosesproses tersebut dapat dibaca pada uraian di bawah ini:

\subsection{Penghitungan Orientasi Tekstur}

Nilai orientasi tekstur berguna untuk memperkirakan bentuk tekstur. Pemetaan orientasi tekstur merepresentasikan tepian citra serta struktur tekstur yang ada pada citra [5]. Untuk citra berwarna, orientasi tekstur suatu vector $(a, b)$ pada bidang kartesian dapat dihitung menggunakan Persamaan 1.

$$
\cos (a, b)=\frac{a \cdot b}{|a||b|}
$$

Dengan

$$
\begin{aligned}
& |a|=\sqrt{R_{x}{ }^{2}+G_{x}{ }^{2}+B_{x}{ }^{2}} \\
& \text { (2) } \\
& |b|=\sqrt{R_{y}{ }^{2}+G_{y}{ }^{2}+B_{y}{ }^{2}}
\end{aligned}
$$

Dimana R, G, dan B masing-masing adalah tingkat kemerahan, kehijauan, dan kebiruan pada citra.

\subsection{Kuantisasi Warna pada Citra}


Kuantisasi warna pada citra dibutuhkan untuk mempermudah proses manipulasi warna. Pada proses kuantisasi ini, nilai RGB citra yang seharusnya berada pada kisaran angka 0-255 diubah ke 0-3.

\subsection{Deteksi Tekston}

Konsep tentang tekston sebenarnya sudah dijelaskan oleh Julesz beserts tim di dalam makalahnya [1]. Oleh karena itu, dalam makalah ini, pembahasan tentang tekston hanya akan diuraikan secara singkat.

Pada makalah ini, tekston yang digunakan adalah tekston yang berukuran $2 \times 2$ dengan model yang dapat dilihat di Gambar 1 . Adapun ilustrasi proses deteksi tekston, dapat dilihat pada Gambar 2.
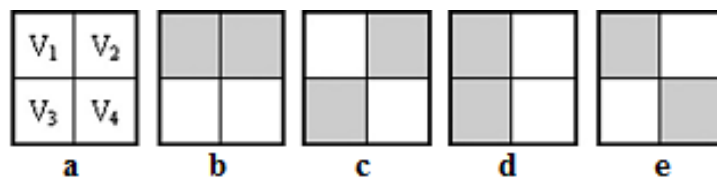

Gambar 1. Model Tekston [5]

Setelah deteksi tekston selesai dilakukan, langkah selanjutnya adalah membuat representasi fitur histogram multi tekston yang peaturannya mengacu pada penelitian Hai-Liu beserta timnya [5].

\subsection{Representasi Fitur}

Dalam penelitian ini, setiap gambar direpresentasikan dengan fitur Histogram multi tekston yang terdiri atas 82 elemen dimana 64 elemen pertama mewakili jumlah tekston dengan warna tertentu dan elemen sisanya mewakili jumlah tekston dengan orientasi tertentu.

Untuk mengukur jarak antar citra, rumus jarak yang digunakan dalam penelitian ini dapat dilihat pada persamaan 4 .

$$
D(T, Q)=\sum_{i=1}^{M} \frac{\left|T_{i}-Q_{i}\right|}{1+T_{i}+Q_{i}}
$$

dimana $D(T, Q)$ adalah jarak antara citra $\mathrm{T}$ dan $\mathrm{Q}, \mathrm{M}$ adalah ukuran histogram multi tekston dari citra yang sedang diukur jaraknya dan $D_{i}$ serta $T_{i}$ adalah nilai elemen ke $i$ dari sebuah histogram.

\section{SISTEM YANG DIUSULKAN}

Seperti judul makalah ini, sistem yang diusulkan adalah sistem pencarian dua fase dengan menggunakan fitur histogram multi tekston. Gambaran umum tentang sistem yang ditawarkan dapat dilihat pada Gambar 3 .

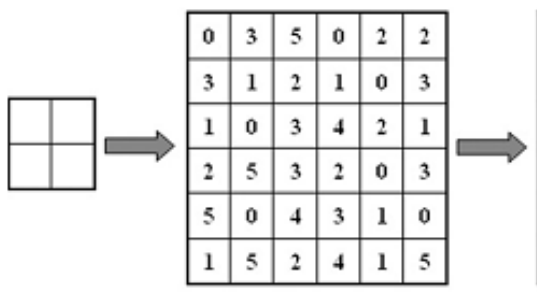

a

b

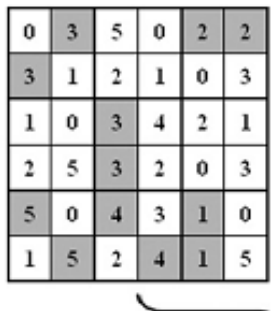

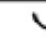

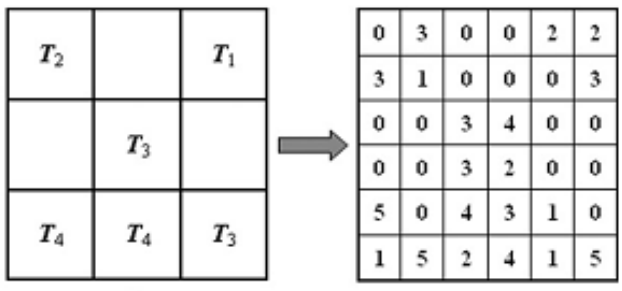

c

d

a) Model Tekston b) Citra Masukan c) Model Tekston yang Ditemukan. d) Hasil Pencarian Tekston

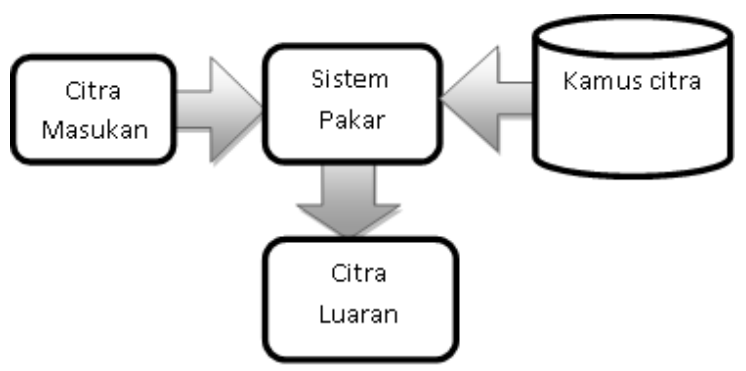

Gambar 3. Gambaran Umum Sistem yang Diusulkan

Pada Gambar 3, kita dapat melihat bahwa sistem memiliki tiga komponen utama yaitu citra masukan, sistem pakar dan dictionary atau kamus citra. Untuk menjelaskan sistem yang diusulkan pada makalah ini, ada dua hal penting yang harus dibahas yaitu rancangan kamus citra dan sistem pakar yang bekerja pada sistem temu kembali citra.

\subsection{Kamus Citra Terklasifikasi}

Seperti namanya, kamus citra berisi data citra semua produk yang dijual. Untuk mendukung sistem pencarian dua fase, kamus citra ini harus 
dirancang sedemikian rupa hingga citra-citra produk tersimpan dalam kondisi terklasifikasi sesuai jenis produk. Nantinya, dari setiap kelas, akan dipilih satu citra sebagai data prototype yang merepresentasikan semua citra yang ada pada kelas masing-masing. Pada sistem ini, kamus citra diklasifikasikan berdasarkan kategori produk semisal produk botol, produk handphone, produk sepatu, produk kamera dan yang lain sebagainya.

\subsection{Sistem Pakar dengan Prosedur Pencarian Dua Fase}

Pada sistem yang diusulkan ini, metode pencarian dibagi menjadi dua fase. Fase pertama berguna untuk mengidentifikasi kelas produk sedangkan fase kedua berguna untuk mengidentifikasi produk secara spesifik.

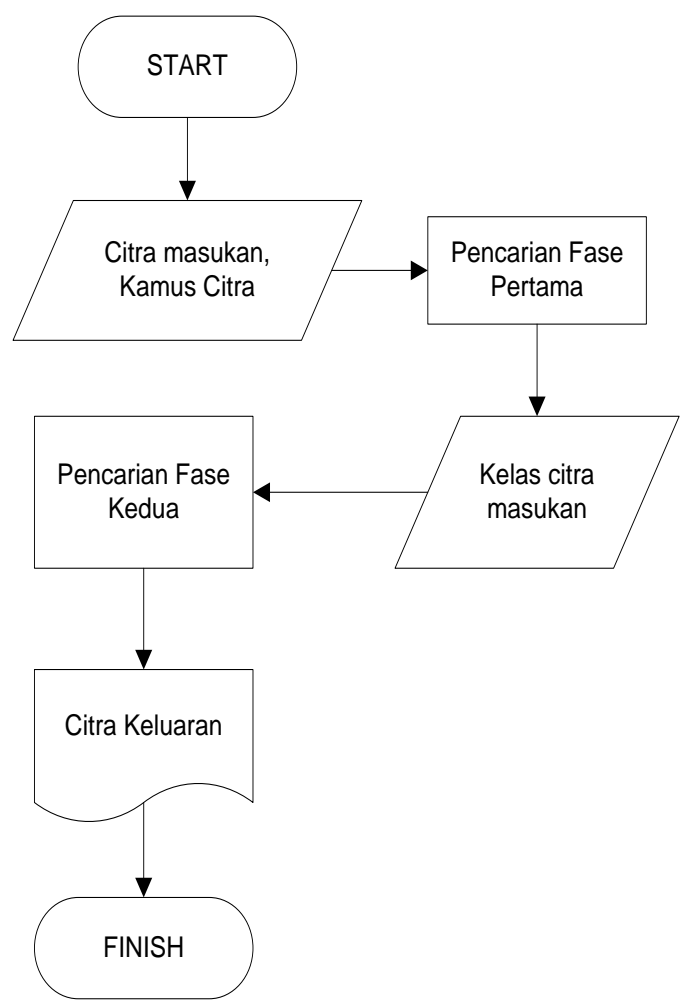

\section{Gambar 4. Gambaran Umum Sistem yang Diusulkan}

Dari sisi kompleksitas, metode pencarian dua fase dapat mengurangi jumlah perulangan pencarian. Sedangkan jika dilihat dari sisi presisi dan recall, sistem pencarian dua fase berpotensi untuk meningkatkan nilai presisi dan recall karena metode ini mempersempit kemungkinan bagi sistem untuk mengembalikan data positif palsu. Adapun gambaran umum tentang sistem pencarian duafase dapat dilihat pada Gambar 4.

\section{SKENARIO DAN HASIL UJI COBA}

Pada bagian ini, akan dijelaskan tentang skenario uji coba, hasil uji coba beserta uraian penjelasan hasilnya. Pada proses uji coba ini, setiap sistem diuji cobakan sebanyak lima puluh kali dengan data masukan dan batas atas jarak antar citra $(\alpha)$ yang berbeda. Validasi pada proses uji coba ini dilakukan dengan metode uji t-student.

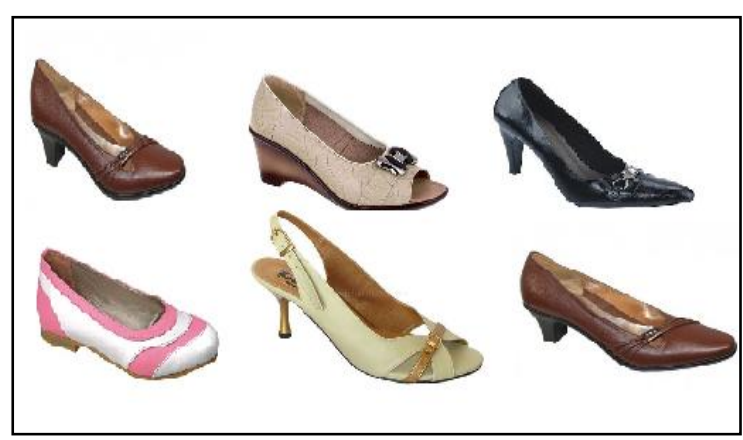

Gambar 5. Gambaran Umum Sistem yang Seharusnya Dikembalikan oleh Sistem 


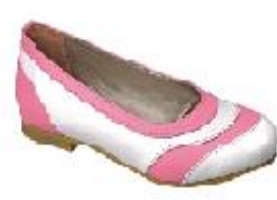

a
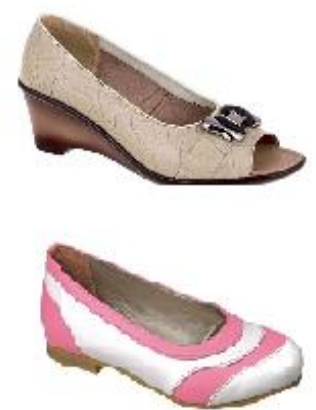

b

Gambar 6. Hasil Pencarian Menggunakan MTH-2 a) Citra masukan. b) Citra luaran

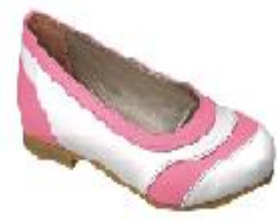

$\mathbf{a}$
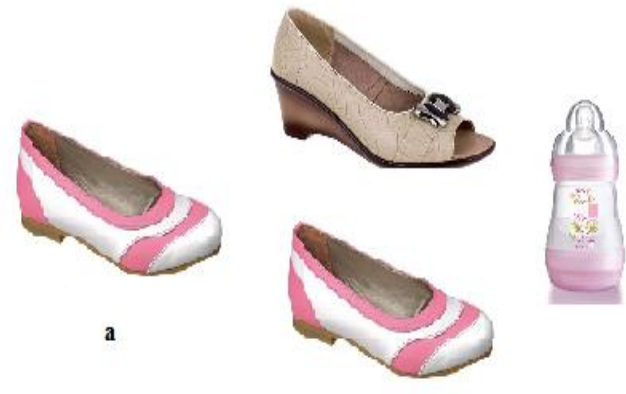

b

Gambar 7. Hasil Pencarian Menggunakan MTH-1 a) Citra masukan. b) Citra luaran

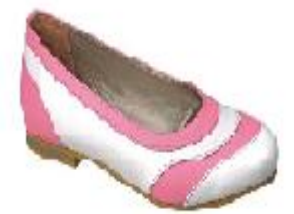

b

Gambar 8. Hasil Pencarian Menggunakan SIFT

a) Citra masukan. b) Citra luaran

\subsection{Data set}

Data set yang digunakan pada penelitian ini terdiri atas 80 citra produk yang terbagi menjadi 6 kelas. Citra dalam dataset ini semuanya berwarna.

\subsection{Sistem Pembanding}

Pada penelitian ini, uji coba diberlakukan kepada tiga sistem temu kembali citra. Sistem pertama adalah sistem histogram multi tekston dengan proses pencarian satu fase atau MTH-1. Sistem yang kedua adalah, sistem adalah sistem histogram multi tekston dengan proses pencarian dua fase atau MTH-2, dan sistem yang terakhir adalah sistem yang menggunakan algoritma SIFT.

\subsection{Hasil Uji Coba}

Hasil dari proses uji coba yang telah dilakukan dapat di lihat pada Tabel 1, Tabel 2, dan Tabel 3. Pada Tabel 1, metode yang diuji adalah metode MTH-2 dengan nilai $\boldsymbol{\alpha}$ yang diperlakukan sebagai variabel independen.

Jika hasil pada Tabel 1 di rata-rata untuk semua produk, MTH-2 dengan $\alpha=0.5$ memiliki nilai presisi rata-rata $60 \%$ dan recall rata-rata sebesar $63 \%$. Sedangkan untuk MTH-2 dengan $\alpha=0.3$ dengan presisi rata-rata $66 \%$ dan recall sebesar $47 \%$.
Nilai recall pada $\alpha=0.5$ lebih baik daripada nilai recall pada $\alpha=0.3$ namun dalam hal presisi berlaku sebaliknya. Tapi disini ada hal yang perlu kita cermati yaitu selisih presisi antara $\alpha=0.5$ dan $\alpha=0.3$ tidak sebanding dengan selisih nilai recall. Sehingga dalam kasus citra produk ini nilai yang disarankan adalah $\alpha=0.5$.

Pada Tabel 2, terdapat tiga sistem yang diuji yaitu sistem MTH-1 dan MTH-2 dengan nilai $\alpha=0.5$ serta sistem yang menggunakan algoritma SIFT.

Dalam hal presisi, sistem yang $\begin{array}{lrrr}\text { Dalam } & \text { hal presisi, } & \text { sistem yang } \\ \text { menggunakan } & \text { SIFT } & \text { paling } & \text { unggul jika }\end{array}$ dibandingkan dengan sistem yang menggunakan MTH-1 dan MTH-2. Sistem yang menggunakan algoritma SIFT hanya menggunakan bentuk sebagai fitur sehingga citra yang dikembalikan sistem adalah citra yang benar-benar mirip dari segi bentuk. Sedangkan pada sistem yang lain, fitur yang dominan adalah fitur bentuk dan tekstur sehingga apabila ada dua citra yang bentuknya agak berbeda namun memiliki tekstur yang sama, keduanya masih dianggap mirip.

Dalam hal recall, sistem yang menggunakan SIFT memiliki performa yang rendah jika dibandingkan sistem yang lain. Penyebabnya masih berkaitan dengan fitur yang dominan. SIFT hanya akan mengembalikan citra yang bentuknya hampir sama persis sehingga produk yang sama namun memiliki sedikit perbedaan model, tidak 
akan dikembalikan. Untuk lebih jelasnya, contoh citra yang dikembalikan oleh ketiga sistem ini dapat dilihat di Gambar 5, Gambar 6, Gambar 7 dan Gambar 8 .

Tabel 1. Hasil Uji Coba Menggunakan Sistem MTH-2 dengan Perubahan Nilai $\alpha$

\begin{tabular}{llll}
\hline Kelas & Nilai $\boldsymbol{\alpha}$ & $\begin{array}{l}\text { Presisi rata- } \\
\text { rata }(\%)\end{array}$ & $\begin{array}{l}\text { Recall rata- } \\
\text { rata(\%) }\end{array}$ \\
\hline Produk 1 & 0.5 & 55 & 100 \\
& 0.3 & 50 & 83 \\
Produk 2 & 0.5 & 83 & 58 \\
& 0.3 & 83 & 50 \\
Produk 3 & 0.5 & 100 & 80 \\
& 0.3 & 88 & 50 \\
Produk 4 & 0.5 & 67 & 58 \\
& 0.3 & 83 & 37 \\
Produk 5 & 0.5 & 34 & 46 \\
& 0.3 & 72 & 26 \\
Produk 6 & 0.5 & 32 & 46 \\
& 0.3 & 29 & 30 \\
\hline
\end{tabular}

Tabel 2. Hasil Uji Coba Menggunakan Sistem MTH-1, MTH-2 dan SIFT

\begin{tabular}{llll}
\hline Kelas & Metode & $\begin{array}{l}\text { Presisi rata- } \\
\text { rata }(\%)\end{array}$ & $\begin{array}{l}\text { Recall rata- } \\
\text { rata(\%) }\end{array}$ \\
\hline Produk 1 & MTH-2 & 55 & 100 \\
& MTH-1 & 20 & 100 \\
& SIFT & 100 & 80 \\
Produk 2 & MTH-2 & 83 & 58 \\
& MTH-1 & 44 & 58 \\
& SIFT & 100 & 72 \\
Produk 3 & MTH-2 & 100 & 80 \\
& MTH-1 & 21 & 80 \\
& SIFT & 100 & 56 \\
Produk 4 & MTH-2 & 67 & 58 \\
& MTH-1 & 59 & 58 \\
& SIFT & 100 & 15 \\
Produk 5 & MTH-2 & 34 & 46 \\
& MTH-1 & 23 & 46 \\
& SIFT & 100 & 20 \\
Produk 6 & MTH-2 & 29 & 46 \\
& MTH-1 & 29 & 46 \\
& SIFT & 100 & 13 \\
\hline
\end{tabular}

Paragraf sebelumnya sudah menguraikan perbedaan metode SIFT dan MTH. Dalam paragraf ini, akan dibahas tentang perbedaan antara MTH-1 dan MTH-2. Gambar 6 dan Gambar 7 adalah hasil pencarian dari sistem temu kembali citra yang sama-sama menggunakan metode MTH. Namun, pada Gambar 7 ada satu Gambar yang tidak dikembalikan di Gambar 6. MTH bekerja dengan fitur warna, tekstur dan bentuk sekaligus. Ketiga fitur ini jika komposisinya seimbang, hasil keluaran sistem temu kembali citra akan bagus. Namun, jika dominasi fitur warna lebih besar dibandingkan fitur tekstur dan bentuk (dalam kasus dua produk berbeda dengan warna yang sama persis), maka produk yang sebenarnya berbeda pun dapat dikembalikan sebagai luaran. Di sinilah terlihat pentingnya mengklasifikasikan kamus citra produk ke dalam beberapa kategori sesuai jenis produknya. Jika dinilai dari segi efektifitas, sistem MTH-2 sama dengan MTH-1 dalam hal recall namun lebih unggul dalam hal presisi. Algoritma SIFT mampu menghasilkan presisi yang hampir sempurna namun dalam hal recall, MTH-2 masih lebih unggul dibandingkan dengan algoritma SIFT. Namun satu hal yang perlu dicatat, ekstraksi fitur pada SIFT memiliki kompleksitas yang lebih tinggi dibandingkan dengan MTH-2 sehingga dari segi biaya komputasi, SIFT dari MTH-2. Dari sini, dapat disimpulkan bahwa MTH-2 lebih efektif jika dibandingkan dengan SIFT.

\section{KESIMPULAN}

Berdasarkan hasil uji coba yang diuraikan pada bagian sebelumnya, dapat ditarik dua poin kesimpulan dan satu poin saran. Pertama, fitur yang paling penting dalam citra produk adalah fitur tekstur dan bentuk. Untuk menghasilkan sistem temu kembali citra yang baik, kedua fitur ini harus ada,

Kesimpulan kedua, adanya sistem klasifikasi pada kamus citra mampu memperbaiki nilai presisi sistem temu kembali citra yang menggunakan fitur MTH meskipun metode ini masih mengandung resiko kesalahan identifikasi kelas produk yang membuat sistem menghasilkan presisi dan recall nol persen.

Saran yang dihasilkan dalam penelitian ini adalah, saat melakukan uji coba sistem temu kembali citra dengan metode dan studi kasus yang sama dengan makalah ini, nilai batas atas jarak antar citra yang layak diuji coba adalah antara 0.3 sampai 0.5. Nilai batas atas yang lebih rendah dari 0.3 akan menghasilkan presisi yang baik namun recallnya rendah sedangkan nilai batas atas yang lebih besar dari 0.5 akan menghasilkan recall yang baik namun presisinya rendah. 


\section{DISKUSI}

Pada ranah penelitian sistem temu kembali citra produk ini, ada dua permasalahan yang perlu dicari solusinya. Permasalahan yang pertama adalah pemilihan gambar prototype untuk mewakili semua Gambar yang ada di kelasnya. Dalam makalah ini, pemilihan Gambar prototype dilakukan dengan cara menghitung jarak rata-rata antar produk untuk semua produk dalam satu kelas selanjutnya, produk yang memiliki jarak rata-rata paling kecil diambil sebagai prototype. Cara ini menghasilkan akurasi sebesar 50\% yang artinya masih harus ditingkatkan lagi.

Masalah yang kedua adalah bagaimana sebaiknya perlakuan kita terhadap fitur warna? Dua kamera pada Gambar 9, secara visual dan matematis memiliki kemiripan bentuk dan kesamaan tekstur namun dua kamera ini memiliki warna yang berbeda. Saat fitur warna dihilangkan dalam uji coba, kedua kamera ini dianggap sama oleh sistem. Namun ketika fitur warna ditambahkan, kedua kamera ini menjadi tidak mirip lagi. Oleh karenanya diperlukan uji coba dan analisa terkait seberapa besar dampak fitur warna terhadap nilai presisi dan recall pada sistem temu kembali citra yang menggunakan fitur histogram multi tekston ini.
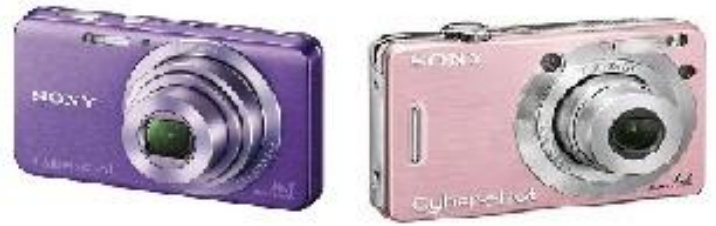

Gambar 9. Dua Gambar yang Memiliki Kedekatan dalam Hal Bentuk dan Tekstur

\section{DAFTAR PUSTAKA}

[1] B. Julesz. 1981. "Textons, The Element of Texture and Their Interaction”. Nature, 291. 91-97.

[2] B.Julesz.1986. "Texton Gradients: The Texton Theory Revisited". Biological Cybernetics 54, 245-251.

[3] D.G Lowe. 2004. "Distinctive Image Points from Scale-Invariant Keypoints Transform”. International Journal of Computer Vision 60. 91-110.

[4] M.Benarjee, M.K Kundu. 2003. "Edge Based Features for Content Based Image Retrieval". Pattern Recognition 36. 2649-2661

[5] G.H. Liu, L. Zhang, Y. Hou, Z. Li and J.Yang. 2010. "Image Retrieval Based on Multitexton
Histogram. Pattern Recognition 43. 23802389 